\title{
Sistem Informasi Perhotelan Berbasis Web Service : Studi Kasus Di Pulau Lombok
}

\author{
(Hotel Information System Based on Web Service - Case Study : Lombok Island) \\ Riris Parahita, Ida Bagus Ketut Widiartha, Ariyan Zubaid \\ Jurusan Teknik Informatika, Fakultas Teknik, Universitas Mataram \\ Jl. Majapahit 62, Mataram, Lombok NTB, INDONESIA \\ Email: parahitariris@gmail.com,widi@ftunram.ac.id, zubaidi13@gmail.com
}

\begin{abstract}
Lombok island has a lot of hotel. The hotel usually have a website that can be visited by tourist to order or just see the information about the hotel. The Tourist need means to obtain information of hotels located on Lombok island in a single website, then a integrated hotel website that can accommodate the information of various hotel in Lombok is needed to fullfill this requirement. This research uses SOAP method to build hotel website and implements a distributed database system that connects DBMS of the same type, compatibility, structure and description of the same data. The system was tested by using the black box methods and questionnaire to 30 students as respondents. The result of the questionanaire showed that the average value of MOS (Mean Opinion Score) is $91.32 \%$. The results of these tests show that the webbased hotel information system is well-functioned and easily understood by users.
\end{abstract}

Keywords: Hotel, web service, SOAP, MOS, DBMS

\section{Pendahuluan}

Hotel adalah sebuah bangunan, perusahaan atau usaha yang menyediakan jasa reservasi kamar hotel dan juga menyediakan makanan dan minuman bagi tamu yang datang serta mempunyai fasilitas jasa lainnya. Hotel juga menyediakan ruangan untuk di jadikan seminar maupun beberapa acara lainnya dan juga memberikan fasilitas yang dibutuhkan pengunjung [4].

Pulau Lombok memiliki banyak tempat wisata yang menarik untuk dikunjungi. Selain memiliki tempat wisata, Lombok juga memiliki banyak hotel yang dapat digunakan sebagai tempat penginapan untuk wisatawan dari berbagai daerah. Hotel yang terdapat di pulau Lombok memiliki jumlah yang cukup banyak, dari hotel yang biaya penginapannya murah sampai yang mahal. Selain itu, dilihat dari pengelompokkan lokasinya di Pulau Lombok juga memiliki business hotel atau city hotel, resort hotel, dan mountain hotel, sehingga wisatawan membutuhkan sarana untuk dapat memperoleh informasi hotel-hotel di Lombok. Dari permasalahan tersebut salah satu solusi yang dapat dilakukan yaitu dengan mengintegrasikan beberapa sistem informasi hotel ke dalam satu wadah yang dapat diakses oleh pengunjung, yaitu dengan membangun website perhotelan di pulau Lombok menggunakan web services dengan metode SOAP. Website perhotelan Lombok dapat dibangun dengan cara mengimplementasikan sistem database terdistribusi yang menghubungkan DBMS yang bertipe sama, kompatibel, struktur dan deskripsi datanya sama.

Penelitian ini dapat mengatasi permasalahan di atas dengan mengelola fitur-fitur yang penting di dalam beberapa sistem perhotelan seperti, lokasi hotel, deskripsi hotel, pemesanan kamar hotel, fasilitas yang ada dan biaya penginapan yang terhubung dengan website hotel yang diinginkan oleh pengunjung. Pihak hotel cukup menyediakan sebuah aplikasi server yang dapat melakukan pengecekan kamar yang dikirimkan oleh web services tersebut.

\section{TINJAUAN PUSTAKA DAN DASAR TEORI}

\section{A. Tinjauan Pustaka}

Aplikasi hotel berbasis web service merupakan salah satu pengembangan perangkat lunak yang dapat memecahkan permasalahan pencarian informasi hotel yang dihadapi masyarakat. Pengembangan teknologi informasi yang sangat pesat saat ini juga berdampak pada perkembangan bisnis melalui jaringan internet. Sistem B2B (Business-to-Businesss) merupakan salah satu sistem yang digunakan dalam bidang bisnis dengan menggunakan teknologi informasi yang dapat dikenal dengan sebutan web service. Web service ini dapat mendukung interopable machine to machine dalam suatu jaringan.

Hasil penelitian terhadap penerapan teknologi web service untuk integrasi layanan puskesmas dan rumah sakit menunjukkan bahwa web service yang berperan sebagai service provider dapat mampu mendukung peran dari service requester, sehingga aplikasi dapat berjalan sesuai dengan kebutuhan sistem. Hasil dari implementasi sistem diperoleh dari pengujian pada masing-masing service yang tersedia pada aplikasi. Dalam penelitian tersebut sistem mampu melakukan pertukaran data dengan menggunakan protokol HTTP melalui sebuah jaringan dan database antara rumah sakit yang berperan sebagai pemberi rujukan yaitu puskesmas ke rumah sakit rujukan yaitu rumah sakit umum (RSU atau AMC) [6]. 
Penelitian tentang penerapan XML web service pada sistem distribusi barang. Dalam penelitian tersebut dengan menggunakan teknologi web service dalam membangun sistem informasi dapat memberikan transaksi data pada proses layanan pemesanan barang dan dapat melakukan pengiriman barang secara lengkap, karena menggunakan XML skema dan tipe data dapat dipantau pada arus transformasi data antara client dan server [2].

Penelitian tentang perancangan XML web service untuk pelaporan transaksi data distribusi obat pada instalasi farmasi menunjukkan bahwa hasil penelitian terhadap komunikasi antar data dengan layanan web service dapat menggunakan protokol terbuka seperti HTTP. Sistem ini dibuat dengan kode pemrograman web services ditulis menggunakan bahasa pemrograman Visual Basic.Net pada framework .net 3.5. Pertukaran antar data dapat menangani proses pelaporan transaksi data distribusi obat. Pengolahan transaksi data yang meliputi penerimaan barang, surat jalan, penjualan resep, dan rektur pembelian.

Dari penelitian dan pembangunan aplikasi serta sistem informasi yang dibuat, maka penulis akan membangun sistem informasi perhotelan bersifat homogen menggunakan web service dengan mengambil studi kasus di pulau Lombok. Web service hotel ini akan membantu user dalam memperoleh informasi pemesanan kamar hotel. Sistem informasi perhotelan ini juga menyediakan fitur-fitur homogen seperti, fasilitas, kamar yang tersedia, biaya penginapan, waktu yang dibutuhkan untuk menempuh hotel,. Web service yang digunakan akan terintegrasi menjadi sebuah layanan yang dapat berinteraksi dengan beberapa website hotel yang homogen di pulau Lombok [7].

\section{B. Dasar Teori}

\section{PHP}

PHP ada salah satu bahasa pemrograman skrip yang dirancang untuk membangun aplikasi web. Ketika dipanggil dari web browser, program yang ditulis dengan PHP akan di-parsing di dalam web server oleh interpreter PHP dan diterjemahkan ke dalam dokumen HTML, yang selanjutnya akan ditampilkan kembali ke web browser. Kerena pemrosesan program PHP dilakukan di lingkungan web server, PHP dikatakan sebagai bahasa sisi server (server-side). Oleh sebab itu, seperti yang telah dikemukakan sebelumnya, kode PHP tidak akan terlihat pada saat user memilih perintah "View Source" pada web browser yang digunakan [3].

\section{SOAP}

SOAP merupakan singkatan dari Simple Object Access Protocol, yaitu protokol standar yang digunakan untuk pertukaran pesan berbasis XML. SOAP menyediakan spesifikasi protokol untuk pertukaran informasi terstruktur dalam implementasi web service.

SOAP adalah standar untuk bertukar pesanpesan berbasis XML melalui jaringan komputer atau sebuah jalan untuk program yang berjalan pada suatu sistem operasi (OS) untuk berkomunikasi dengan program pada OS yang sama maupun berbeda dengan menggunakan
HTTP danXML sebagai mekanisme untuk pertukaran data.SOAP berfungsi seperti sebuah amplop yang digunakan untuk pertukaran data object di dalam network. SOAP mendefinisikan empat aspek didalam komunikasi. Message envelope, Encoding, RPC call convention, dan bagaimana menyatukan sebuah message di dalam protokol transport. Sebuah SOAP message terdiri dari SOAP Envelop dan bias terdiri dari attachments atau tidak memiliki attachment. SOAP envelop tersusun dari SOAP header dan SOAP body, sedangkan SOAP attachment membolehkan non-XML data untuk dimasukkan ke dalam SOAP message, di-encoded, dan diletakkan ke dalam SOAP message dengan menggunakan MIME- multipart [5].

3. CodeIgniter

CodeIgniter (CI) adalah suatu framework pengembangan aplikasi web berbasis PHP. CI menyediakan banyak library sehingga memungkinkan mengembangkan aplikasi dengan lebih cepat. CodeIgniter dibuat pertama kali oleh Rick Ellis, CEO perusahaan Ellislab, Inc. Adapun keuntungan menggunakan CodeIgniter sebagai berikut:

a. CodeIgniter termasuk framework sederhana dengan ukuran kecil, namun memiliki kemampuan besar.

b. CodeIgniter dieksekusi dengan cepat dan memiliki performance yang handal.

c. Menerapkan konsep Model-View-Controller (MVC).

d. Aplikasi yang dibuat dengan CodeIgniter kompatibel dengan standar hosting yang menjalankan beberapa versi PHP dan konfigurasi yang berbeda.

e. Dokumentasi CodeIgniter lengkap dan jelas.

Dengan ukuran yang relatif kecil, CodeIgniter dilengkapi dengan fitur-fitur yang cukup banyak. Fiturfitur utama CodeIgniter diantaranya [1]:

a. Mendukung beberapa macam database.

b. Mendukung "active record" untuk mengakses database.

c. Validasiform.

d. Security dan XSS filtering.

e. Pengaturan Session.

f. Class Email.

g. Library untuk mengolah gambar.

h. Fileupload.

i. FTP.

j. Localization (lokalisasi bahasa).

k. Pagination.

1. Dataencryption.

m. Fullpagecaching.

n. Errorlogging.

o. Application profiling.

p. Class user agent.

q. Class zip encoding.

r. XML-RPC.

s. Flexible URI-routing.

t. Searchenginefriendly URL. 
u. Memiliki banyak Helper untuk berebagai keperluan.

\section{METODE PENELITIAN}

Bagian ini menjelaskan metode penelitian yang dilakukan terhadap sistem informasi perhotelan Lombok dengan menggunakan teknologi web service.

\section{A. Langkah-Langkah Penelitian}

Bagian ini menjelaskan langkah-langkah yang ditempuh dalam penulisan tugas akhir, berikut alur kerja yang dipresentasikan pada gambar 1 .

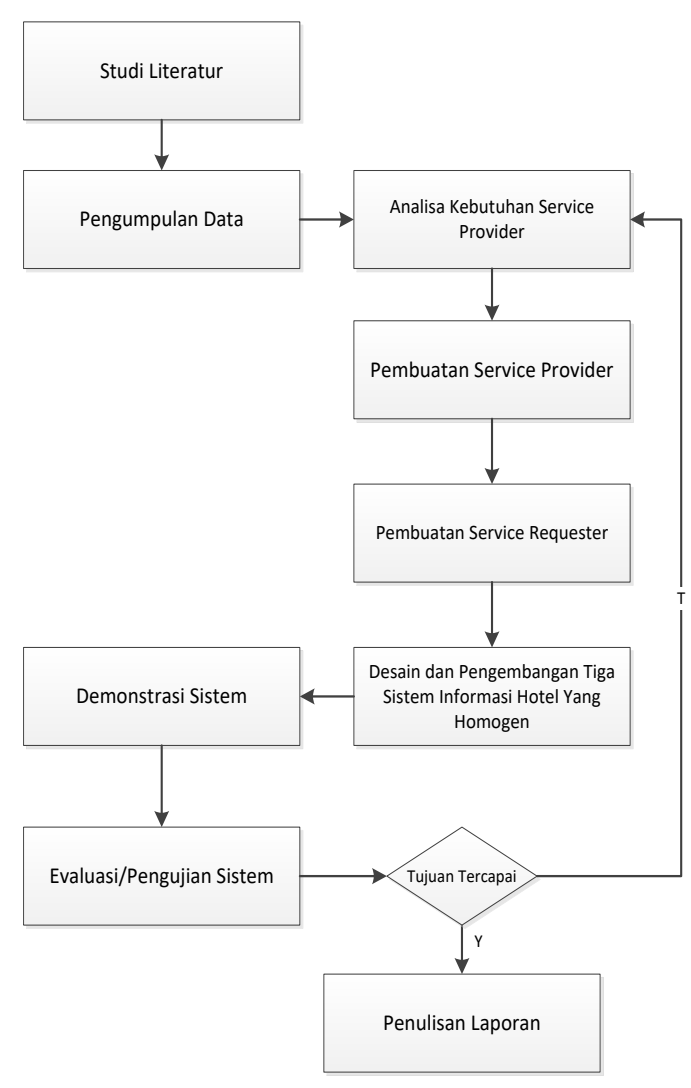

Gambar 1. Diagram Blok Proses Penelitian

Metodologi penelitian menjelaskan tentang alur kerja penelitian, antara lain :

a. Studi literatur

Studi literatur menjelaskan tentang dasar teori yang digunakan untuk menunjang penulisan tugas akhir. Dasar teori pendukung tersebut meliputi :

1. Web services

2. Bahasa pemrograman yang digunakan seperti HTML, PHP, dan JavaScript.

3. Framework yang digunakan adalah Coedeigniter dan bootstrap.

4. Menggunakan PHP, HTML, XML, javascript, layanan pendukung web service, codeigniter dan bootstrap.
Literatur tersebut diperoleh dari buku, jurnal, dan paper.

b. Pengumpulan data

Pengumpulan data merupakan tahap pencarian data yang dibutuhkan dalam penelitian dan perancangan sistem informasi perhotelan berbasis web services yaitu dengan studi kasus data tiga hotel di pulau Lombok. Data yang dibutuhkan untuk menunjang perancangan dan pembuatan sistem informasi perhotelan di Lombok yaitu data hotel yang meliputi:

1. Nama hotel

2. Lokasi hotel

3. Deskripsi hotel

4. Fasilitas hotel

5. Ketersediaan kamar

6. Biaya kamar hotel

c. Analisa kebutuhan service provider

Mendiskripsikan tentang kebutuhan untuk menyediakan semua hal berdasarkan fitur homogen pada sistem dalam penelitian dan perancangan sistem informasi perhotelan berbasis web services studi kasus di pulau Lombok

d. Pembuatan service provider

Pembuatan service provider dilakukan untuk membuat konten atau layanan homogen yang dibutuhkan dalam sistem web perhotelan di pulau Lombok.

e. Pembuatan service requester merupakan layanan untuk pemesanaan kamar hotel dalam sistem web perhotelan sehingga pengguna dapat memperoleh informasi tentang hotel di pulau Lombok.

f. Desain dan Pengembangan Tiga Sistem Informasi Hotel Yang Homogen

Tahap ini merupakan tahap merancang alur kerja sistem dan interface yang berfungsi untuk memudahkan dalam implementasi tiga website sistem informasi perhotelan yang homogen berbasis web services studi kasus di pulau Lombok.

g. Demonstrasi sistem

Demonstrasi sistem merupakan implementasi keluaran dan tampilan dari sistem informasi perhotelan berbasis web services studi kasus di pulau Lombok. Implementasi sistem dilakukan berdasarkan tahap desain dan pengembangan sistem.

h. Evaluasi/ Pengujian sistem

Pengujian atau evaluasi sistem merupakan tahap yang berfungsi untuk mengetahui fungsionalisme sistem informasi perhotelan berbasis web services studi kasus di pulau Lombok

i. Penulisan Laporan

Penulisan laporan meliputi hasil akhir dari penelitian berdasarkan pengujian sistem informasi perhotelan berbasis web services studi kasus di pulau Lombok.

Perancangan aplikasi pada penelitian ini dimulai dari perancangan arsitektural, flowchart, usecase diagram, sequence diagram, activity diagram, hubungan antar 
entitas pada sistem, perancangan database, dan perancangan interface.

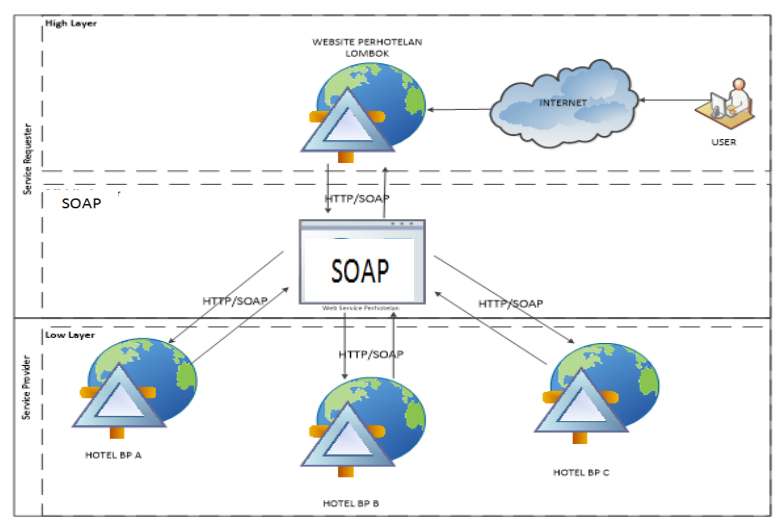

Gambar 2. Perancangan arsitektur web service perhotelan.

Dalam arsitektural perancangan sistem ini dibagi menjadi dua service, antara lain :

1. Service Requester ialah yang meminta layanan web service melalui web perhotelan Lombok yang dapat diperoleh dari service eprovider.

2. Service Provider adalah penyedia layanan web service terhadap tiga informasi web perhotelan Lombok yang homogen dapat diakses oleh user.

Gambar 2 mengilustrasikan tentang arsitektur sistem informasi perhotelan di Lombok menggunakan web services. Pengunjung web harus terhubung dengan jaringan internet untuk dapat mengakses web perhotelan. Website perhotelan ini menyediakan informasi beberapa hotel yang berada di Lombok. Dalam perancangan dan pembuatan sistem ini, akan dimungkinkan pertukaran data antar basis data, baik data dari database hotel A, hotel B dan hotel C ke website perhotelan melalui web service dan sebaliknya, sehingga pengunjung web atau pengguna dapat melakukan pemesanan hotel secara online. Pertukaran data tersebut berbasis XML dan menggunakan metode SOAP (Simple Oject Access Protocol) yang berguna untuk proses transaksi melalui HTTP. SOAP membuat client web service dapat memilih beberapa parameter mengenai permintaannya dan memberikannya kepada penyedia. Ketika penyedia menanggapi permintaan tersebut, maka terjadilah web sevice.

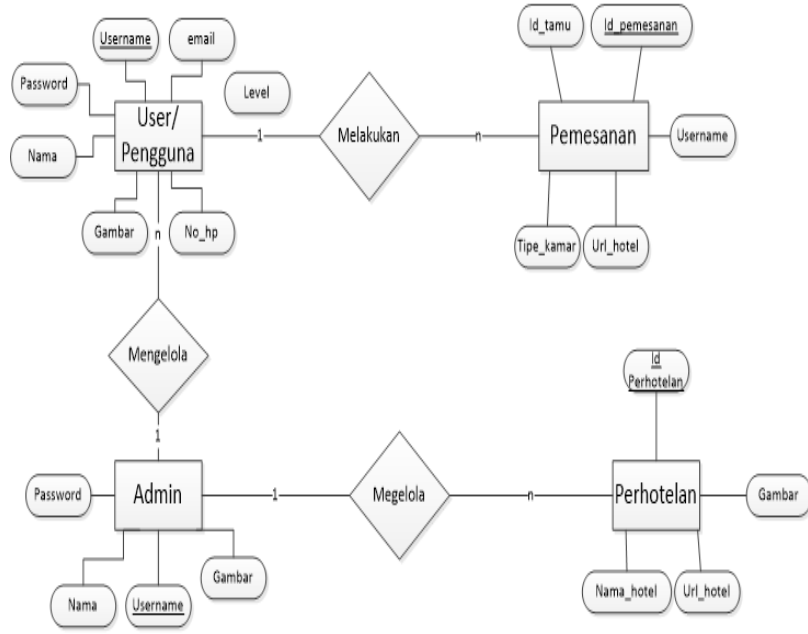

Gambar 3. Diagram Hubungan Antar Entitas Untuk Perhotelan Lombok

Gambar 3 merupakan entity relationship diagram dari sistem informasi website perhotelan di Lombok. Terdapat empat entitas, yaitu entitas user atau pengguna, entitas perhotelan, entitas pemesanan, entitas admin, dan entitas booking . Entitas user dihubungkan dengan entitas pemesanan melalui decision melakukan, sedangkan entitas admin dihubungkan dengan perhotelan melalui decision mengelola. Entitas user memiliki tujuh atribut, antara lain email, password, nama, gambar, no_hp, level, dan username sebagai primery key. Entitas pemesanan memiiki atribut id_tamu, tipe_kamar, url_hotel, username sedangkan id pemesanan sebagai primery key dari entitas pemesanan. Entitas perhotelan memiliki emapat atribut, yaitu gambar, nama_hotel, url_hotel dan id perhotelan sebagai primery key. Entitas admin memiliki empat atribut yaitu username, password, gambar, dan nama yang terhubung dengan entitas useratau pengguna melalui decision mengelola.

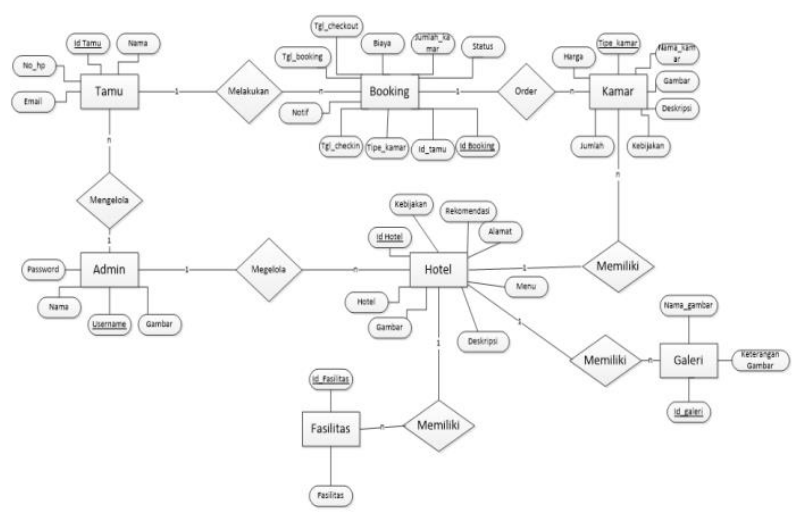

Gambar 4 Diagram Hubungan Antar Entitas Untuk Hotel A/B/C

Gambar 4 merupakan diagram hubungan antar entitas untuk masing-masing hotel yaitu hotel A, hotel B, dan hotel C. Terdapat tujuh entitas diantaranya yaitu entitas tamy, admin, booking, kamar, hotel, galeri, dan fasilitas. Entitas admin mengelola entitas tamu dan mengelola entitas hotel. Entitas tamu berhubungan dengan 
entitas booking melalui decision melakukan. Entitas hotel memiliki kamar, galeri, dan fasilitas.

\section{B. Rancangan Site Map Website Perhotelan Lombok}

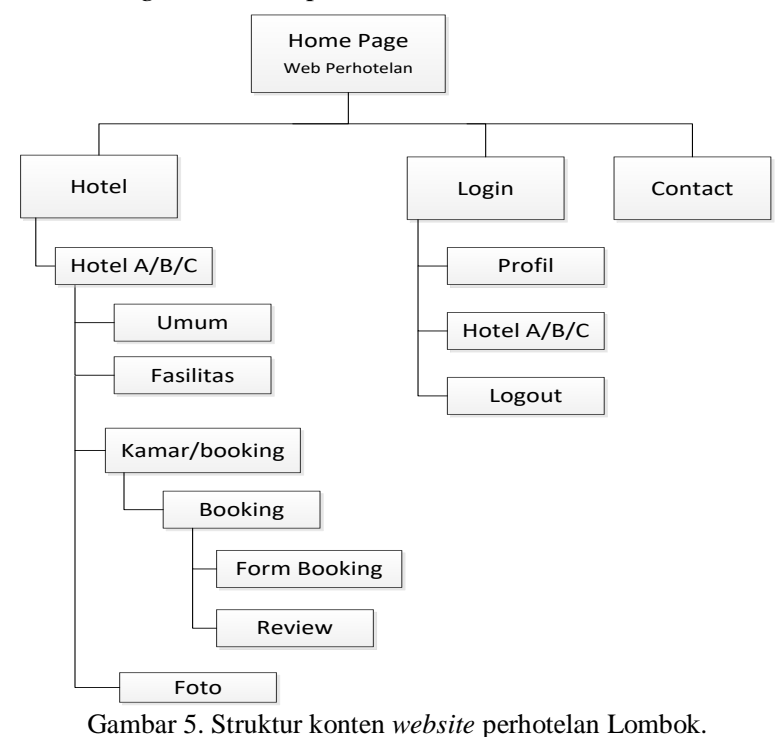

Gambar 5 merupakan rancangan struktur denah pada website perhotelan Lombok yang menyediakan konten maupun artikel secara menyeluruh. Website perhotelan berbasis web service studi kasus di Pulau Lombok ini menyediakan tiga konten. Konten pertama bernama hotel yang memiliki empat sub menu, yaitu umum, fasilitas, kamar/booking, dan foto. Pada menu kamar/booking terdapat sub menu booking yang berisi form booking dan review. Konten kedua yaitu menu login, yang menyediakan informasi hotel, profil dan logout, sedangkan konten ketiga adalah contact yang berisi kontak admin yang dapat dihubungi oleh user.

\section{HASIL PENGUJIAN DAN PEMBAHASAN}

\section{A. SOAP Server Pada Sistem}

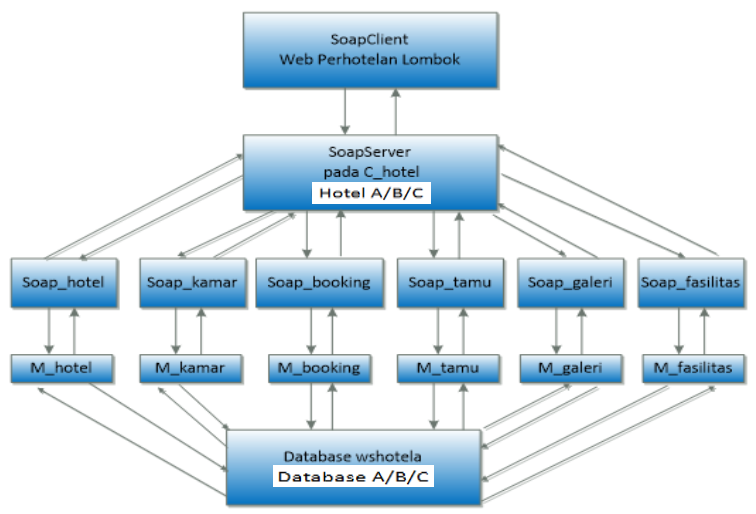

Gambar 6. Struktur SOAP Hotel A/B/C.

Gambar 6 merupakan struktur yang mengilustrasikan alur kerja SOAP. Pada SOAP website hotel A berperan sebagai server. Implementasi salah satu fungsi pertukaran data dengan menggunakan SOAP yang terdapat pada folder model website hotel A dengan nama $\mathrm{m}$ _hotel. File m_hotel merupakan model yang akan diakses untuk pertukaran data-data yang terdapat pada tabel hotel.

\section{B. Interface Web Perhotelan Lombok}

Gambar 7 merupakan interface pada halaman utama website perhotelan yang akan diakses oleh user. Pada bagian atas tampilan terdapat menu daftar hotel, login, daftar, contact dan about. Menu daftar hotel merupakan daftar hotel-hotel yang terdapat di Lombok. Login dapat digunakan oleh user untuk memudahkan memesan kamar hotel yang diinginkan. Menu daftar merupakan menu yang digunakan untuk melakukan daftar sebagai user, sehingga dapat melakukan login. Contact dan abaut merupakan halaman pada website perhotelan untuk mengetahui kontak yang dapat dihubungi bila ada suatu kendala, sedangkan menu about dapat berisi tentang tujuan dan manfaat dibuat website perhotelan.

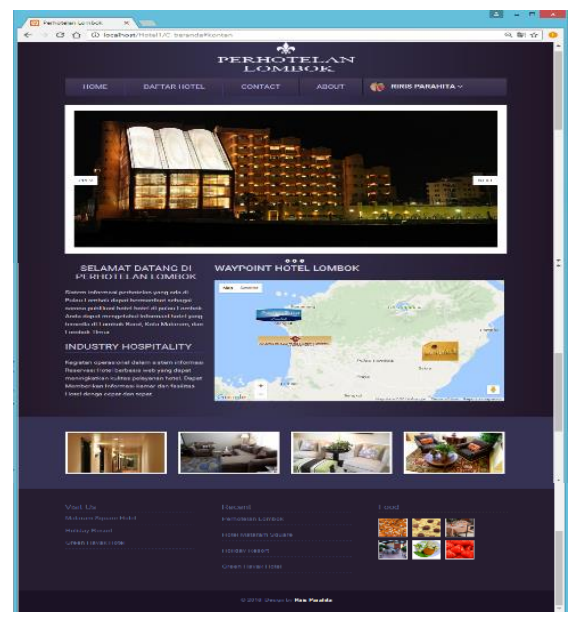

Gambar 7 Interface Utama Perhotelan.

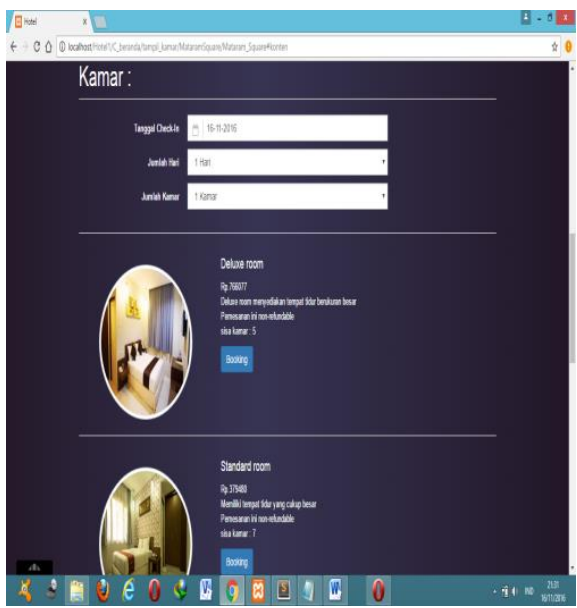

Gambar 8 Interface Daftar kamar Hotel.

Gambar 8 menampilkan tipe kamar yang disediakan oleh hotel, tampilan pada website perhotelan Lombok yang dapat dilihat oleh user. Pada interface tersebut 
terdapat foto kamar, nama tipe kamar, deskripsi singkat tentang kamar, dan harga masing-masing kamar. Untuk melakukan booking kamar, user dapat mengklik buttonbooking yang tersedia pada masing-masing tipe kamar yang akan dipesan.

Gambar 9 juga dapat menunjukan interface untuk melihat tipe kamar yang disediakan oleh masing-masing hotel. Pada website perhotelan menampilkan foto pada masing-masing tipe kamar dan harga. User dapat melakukan booking kamar dengan cara mengklik button booking yang tersedia pada masing-masing tipe kamar hotel.

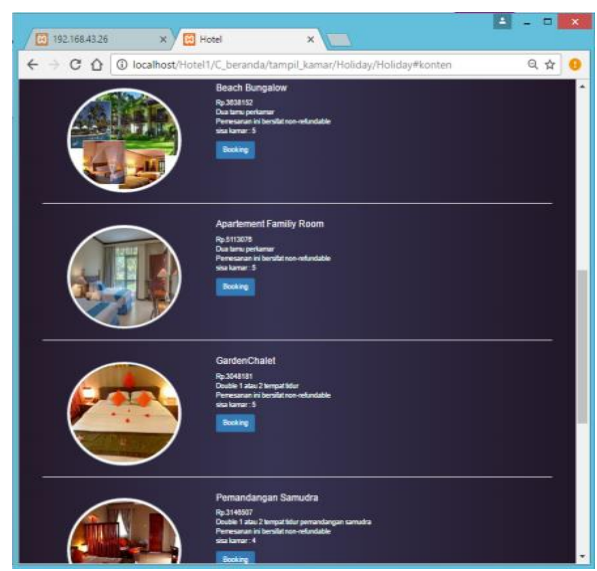

Gambar 9 Interface lihat kamar.

Pada interface kamar hotel terdapat form yang digunakan user untuk proses pemesanan kamar hotel. Pada form terdiri dari tanggal check-in, jumlah hari, dan jumlah kamar, terlihat pada gambar 10.

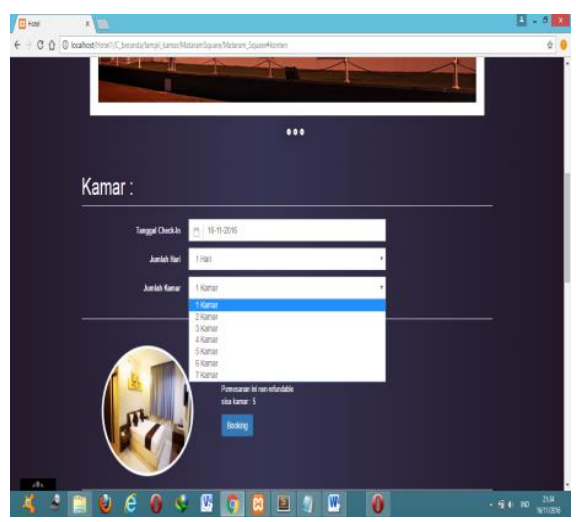

Gambar 10 Interface Form Pada Menu Kamar.

User yang telah memiliki akun dan melakukan login, maka user dapat melihat profil yang dapat ditunjukkan pada gambar 11. Konten yang terdapat pada profil user antara lain foto pengguna, username, password, nama pengguna, nomer hp dan email. Interface profil juga dapat menampilkan data-data pemesanan kamar yang direperesentasikan dalam bentuk tabel. Tabe pemesanan terdiri dari nomer, id tamu, tipe kamar, tanggal check-in, tanggal check-out, jumlah kamar, dan biaya. Selain itu, user dapat mengetahui status pemesanan, apakah sudah diterima oleh pihak hotel yang bersangkutan atau masih menunggu konfirmasi dari pihak hotel tersebut, serta memiliki status ditolak apabila dalam waktu 24 jam dari tanggal booking tidak diperoses lebih lanjut oleh user.

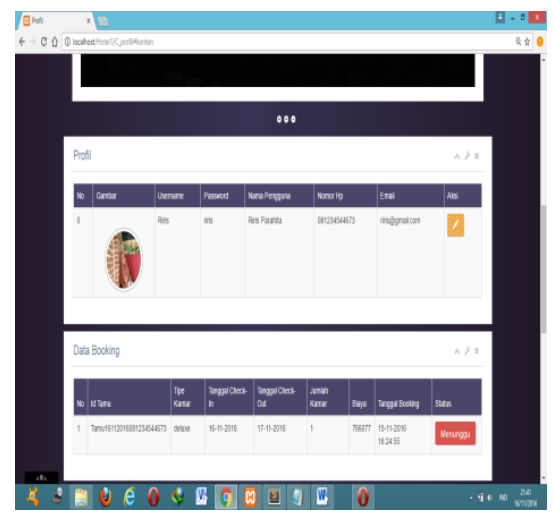

Gambar 11 Interface profil user.

\section{Hasil Pengujian}

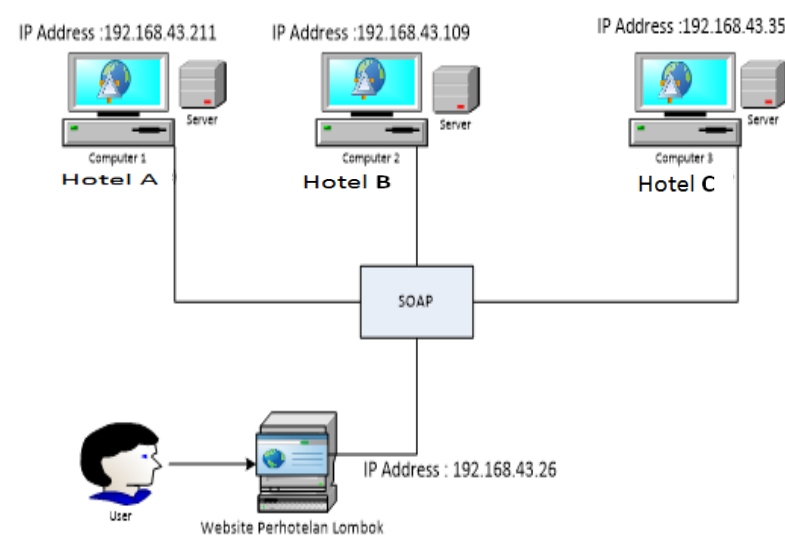

Gambar 12 Setting IP Address.

Bagian ini memuat penjelasan mengenai pengujian terhadap sistem yang telah diimplementasikan. Metode pengujian yang digunakan telah dijelaskan pada bab tiga yaitu menggunakan metode black-box, dimana merupakan pengujian yang memperhatikan masukan dan keluaran akhir dari usecase yang dijalankan. Dalam pengujian ini juga menggunakan satu jaringan yang sama terhadap empat sistem website tersebut, dimana masing-masing sistem diatur IP addressnya, sehingga dapat saling terhubung untuk melakukan pertukaran data seperti ditunjukkan pada gambar 4.90. Komputer 1 digunakan untuk menguji sistem website hotel A dengan IP Address 192.168.43.211. Komputer 2 digunakan dalam pengujian website B dengan pengaturan IP Address 192.168.43.109, dan komputer 3 berperan dalam pengujian website hotel C dengan IP Address 192.168.43.35. Komputer 1, komputer 2 , dan komputer 3 akan terhubung dengan komputer 4 
yang merupakan website perhotelan Lombok, dimana IP Addressnya adalah 192.168.43.26. Apabila keempat komputer sudah terhubung, maka web service yang berfungsi untuk pertukaran data dapat berhasil dilakukan.

Pengecekkan status booking. User yang dapat mengetahui status booking adalah user yang telah memiliki akun, sehingga status booking dapat dilihat pada menu profil. Pengecekkan diproses setelah melakukan login. Komputer 4 yang merupakan website perhotelan Lombok akan mengecek kesetiap komputer yang terhubung, untuk mengetahui status data booking apakah diterima, dibatalkan, atau menunggu.

\section{KESIMPULAN DAN SARAN}

Berdasarkan penelitian yang telah dilakukan dalam implementasi web service pada sistem inforasi perhoelan Lombok maka diambil kesimpulan sebagai beerikut :

1. Web service dapat digunakan untuk membangun sistem informasi perhotelan Lombok dalam melakukan pertukaran data yang terhubung denagn server dan dapat meyediakan layanan client.

2. Sistem informasi perhotelan yang telah dibuat dapat menampilkan data-data dari server, seperti nama hotel, lokasi hotel, deksripsi, kebijakan, data kamar, fasilitas, dan galeri.

3. Penelitian ini berhasil membagun aplikasi client berbasis web dengan menggunakan web service guna mendapatkan dan menampilkan data-data dari server berupa informasi hotel dan pemesanan kamar.

4. Berdasarkan hasil pengujian kuisioner dengan nilai rata-rata MOS yaitu 91,32\%. Hasil pengujian tersebut menunjukan bahwa sistem berjalan dengan baik dan mudah dipahami pengguna.

Adapun saran yang dapat disampaikan untuk pengembangan sistem lebih lanjut adalah sebagai berikut:

1. Pengembangan sistem perhotelan Lombok ini untuk kedepannya diharapkan dapat menambahkan layanan pembayaran sehingga lebih memudahkan pengguna dalam melakukan transaksi.

2. Sistem informasi perhotelan Lombok yang telah diimplementasikan dengan menggunakan struktur tabel database yang kurang bervariasi, maka diharapkan kedepannya dalam pengembangan database dapat menggunakan struktur tabel yang lebih lengap dan berbeda pada tiap hotelnya.

3. Sistem web perhotelan yang dibuat hanyan menerapkan sedikit keamanan sehingga diharapkan dalam pengembangan sistem selanjutnya dapat membahas keamanan jarigan pada web service.

\section{REFERENCES}

[1] Alatas, H., 2013, Responsive Web Design dengan PHP dan Bootstrap, Loko Media, Yogyakarta.

[2] Deviana, H., 2011, Penerapan XML Web Service Pada Sistem Distribusi Barang, Jurnal Generic, Vol.6, No.2, pp.61-70..

[3] Lucky ., 2010, XML Web Service dan Internet, Jasakom, Yogyakarta.

[4] Rachman, A.A., 2005, Ilmu Perhotelan dan Restoran, Graha Ilmu, Yogyakarta.

[5] Rizky, S., 2008, Sistem Informasi Terintegrasi Menggunakan XML Web Service, Cerdas Pustaka, Jakarta.

[6] Rokhmat, H., Ashari, A., 2013, Penerapan Teknologi Web Service Untuk Integrasi Layanan Puskesmas dan Rumah Sakit, Tesis, S2 Ilmu Komputer UGM, Yogyakarta.

[7] Setiawan, A., 2008, Perancangan XML Web Service Untuk Pelaporan Transaksi Data Distribusi Obat Pada Instalasi Farmasi, Skripsi, S1 Teknik Elektro Universitas Diponegoro, Semarang. 